\title{
Editorial
}

\section{Recent Advances in Diagnosis of Cancer}

\author{
Lt Gen JR Bhardwaj, PVSM, AvsM, vsM, PHS
}

MJAFI 2005; 61 : 112-114

Key Words: Oncology; Molecular; Markers

"Cancer biomarkers" constitutes one of the most rapidly advancing fields in clinical diagnostics. They can be used to screen asymptomatic individuals in the general population, to assist in early and specific diagnosis in suspect cases, to select patients who may benefit from specific treatments, to predict prognosis and response to therapy and finally to monitor patients after primary therapy.

The introduction of advanced sophisticated technologies like microarray, mass spectrometry and automated DNA sequencing have opened new avenues in the field of "Cancer biomarkers". But by this world of mechanization, is light microscopy being lost in the thick dense forests? Let us critically analyze the assets and limitations of all these newer methodologies.

Conventional histopathology based on assessing morphology has remained the standard diagnostic method for many years. The use of enzyme histochemistry and electron microscopy expanded the primary micro-anatomic evaluation to include biochemical and sub-cellular ultra-structural features. More recently, we have progressed and immuno-histochemistry, cytogenetics, analysis of DNA ploidy and molecular genetic assays have been added as valuable adjuncts to light microscopy in cancer diagnosis.

Oncologic imaging has also undergone remarkable advances. The imaging paradigm is shifting from anatomic and spatial 2D and 3D images to a focus on molecular, functional, biologic and genetic imaging. Various modalities in diagnostic and prognostic oncology will be reviewed. These bear interest to all laboratory medicine experts, medical and surgical oncologists and allied specialties.

Immuno-histochemistry is a well-established technique based on the detection of specific protein sequences (antigenic determinants) of tumors by the use of antisera and monoclonal antibodies directed against them. It is of paramount importance in unclassified tumors such as undifferentiated tumors, small round blue cell tumors and lymphoid malignancies in particular. The common immunohistochemical panels used are cytokeratin for epithelial malignancies, leucocyte common antigen for lymphomas, S-100 protein for neural and neuroectodermal differentiation, HMB-45 for melanomas, desmin and vimentin for tumors exhibiting muscle and mesenchymal differentiation respectively. This also helps in metastatic tumors of unknown primary to direct further therapeutic decisions by delineating the origin of the tumor.

Immuno-histochemistry has been utilized extensively to determine estrogen, progesterone and Her-2 neu receptor status in breast cancer in predicting response to therapy [1].

Yet other antibodies directed against proteins involved in the regulation of cell cycle like cyclin D1 and E have been reported to be of prognostic significance in breast cancer and squamous cell carcinoma of head and neck.

Molecular Oncology is another field where distinctive abnormalities of genetic structure and gene expression of the cancer cell are studied. The resultant abnormalities of the cell cycle lead to dysregulated proliferation of cancer cells. Solid tumors are characterized by multiple specific and non specific changes, while lymphomas and leukemias are distinguished by highly specific cytogenetic and molecular genetic rearrangements. These changes are being analyzed on chromosomes, DNA or RNA and are finger printed by molecular techniques.

Chromosomal aberrations are frequently encountered in malignant cells and are often distinctive of a specific tumor type. Chromosomal alterations can be of varied types. These include, duplications (addition of chromosome), deletions (loss of whole or parts of chromosomes), segmental amplifications (random reiteration of segments or extra fragments), translocations (exchange between chromosomes) and

Director General Armed Forces Medical Services \& Senior Colonel Commandant, Army Medical Corps, Professor of Pathology, Army Hospital (R\&R), Delhi Cantt-110010. 
inversions (reversal of orientation). Bone marrow aspirate samples can be used in hematological malignancies to recognize individual abnormalities. Banding analysis of metaphase chromosome has been the traditionally performed method for detection of chromosome abnormalities [2]. However, an analysis of chromosomal abnormalities in solid tumors has historically been taxing and laborious using tissue sections.

The technique of Fluorescence in situ hybridization (FISH) is applicable to interphase cells. Hence, it is more sensitive compared to conventional cytogenetics [3]. Comparative genomic hybridization $(\mathrm{CGH})$ is a newly described method that globally assays for chromosomal gains and losses in genomic complement. These newer advanced techniques appear more promising as of today.

Identification of the cancer gene along with its structural aberrations has become essential to identify, as many mutations are not discernible at the cytogenetic level. Documented gene alterations are based on analyses of oncogenes, tumor suppressor genes, DNA repair genes and regulators of apoptosis.

Molecular methods detect signature nucleotide sequences within the repertoire of the nucleic acid content of a cell and hence enable us to distinguish between benign and malignant cells. Cellular DNA is analyzed using Southern Blot (SB) procedure or Polymerase Chain Reaction (PCR)[4]. Messenger RNA (mRNA) detection of genes and their products is done by the techniques like northern blot, reverse transcription-PCR (RT-PCR) and in situ hybridization.

Relatively newer techniques like microarray, allow measurement of differential expression of a distinct gene complement in different histo-morphological types and grades of a particular tumor[5]. This method can also profile the degree and type of genes which are activated or suppressed at a given point of time in a spectrum of malignancies. All these methods are highly sensitive but critical analysis needs to be performed before establishing a cause effect relationship. Diagnostic molecular markers for some malignancies are depicted in Table 1.

Measurement of tumor markers levels, when used along with other diagnostic tests, can be useful in the detection and diagnosis and follow up of some type of cancers. They are biologic or biochemical substances produced by tumors and secreted into blood, urine, other body fluids or body tissues of some patients with certain types of cancer in higher than normal amounts. A tumor marker may be produced by tumor itself, or by the body in response to the presence of cancer or certain noncancerous conditions [6]. Some examples of the most
Table 1

Selected molecular genetic markers in cancer diagnosis

\begin{tabular}{|c|c|c|}
\hline Disease & Marker & Method \\
\hline CML & $\begin{array}{l}\mathrm{t}(9 ; 22)(\mathrm{q} 34 ; \mathrm{q} 11) \\
{[\mathrm{BCR} / \mathrm{ABL}]}\end{array}$ & SB, RT-PCR, FISH \\
\hline CLL & Trisomy 12 & FISH \\
\hline ALL & $\begin{array}{l}\mathrm{t}(9 ; 22)[\mathrm{BCR} / \mathrm{ABL}] \\
\mathrm{t}(1 ; 19)[\mathrm{E} 2 \mathrm{~A} / \mathrm{PBX}] \\
\mathrm{t}(8 ; 14), \mathrm{t}(2 ; 8), \mathrm{t}(8 ; 22) \\
\mathrm{t}(4 ; 11)\end{array}$ & $\begin{array}{l}\text { RT-PCR, FISH } \\
\text { SB, FISH } \\
\text { RT-PCR, FISH }\end{array}$ \\
\hline AML & & \\
\hline $\begin{array}{l}\text { M2 } \\
\text { M3 } \\
\text { M4 Eo }\end{array}$ & $\begin{array}{l}\mathrm{t}(8 ; 21)[\mathrm{AML} 1 / \mathrm{ETO}] \\
\mathrm{t}(15 ; 17)[\mathrm{PML} / \mathrm{RARA}] \\
\text { inv } 16[\mathrm{MYH} 11 / \mathrm{CBFb}]\end{array}$ & SB, RT-PCR, FISH \\
\hline NHL all cases & $\begin{array}{l}\text { Antigen receptor gene } \\
\text { rearrangement }\end{array}$ & SB, PCR \\
\hline Follicular NHL & $\mathrm{t}(14 ; 18)[\mathrm{BCL} 2 / \mathrm{IGH}]$ & $\mathrm{SB}, \mathrm{PCR}$ \\
\hline Burkitt's lymphoma & $\begin{array}{l}\mathrm{t}(8 ; 14), \mathrm{t}(2 ; 8), \mathrm{t}(8 ; 22) \\
{[\mathrm{MYC} ; \mathrm{IGH} / \mathrm{IGK} / \mathrm{IGL}]}\end{array}$ & $\mathrm{SB}, \mathrm{FISH}$ \\
\hline $\begin{array}{l}\text { Ewings family of } \\
\text { tumours }\end{array}$ & $\mathrm{t}(11 ; 22)[\mathrm{FL} 11 / \mathrm{EWS}]$ & $\mathrm{SB}, \mathrm{FISH}$ \\
\hline Neuroblastoma & MYCN amplification & $\mathrm{SB}, \mathrm{FISH}$ \\
\hline Breast Cancer & $\begin{array}{l}\text { HER2/NEU/ERBB2 } \\
\text { Amplification }\end{array}$ & SB, FISH \\
\hline Bladder Cancer & p53 mutation & PCR \\
\hline $\begin{array}{l}\text { Head and neck } \\
\text { cancers }\end{array}$ & p53 mutation & PCR \\
\hline Colon & $\mathrm{K}$ ras mutation & PCR \\
\hline
\end{tabular}

CML - Chronic myeloid leukemia; CLL - Chronic lymphocytic leukemia; ALL - Acute lymphoblastic leukemia; AML - Acute myeloid leukemia; NHL - Non-Hodgkin's lymphoma; SB - Southern blot hybridization; FISH - Fluorescent in-situ hybridization; PCR Polymerase chain reaction; RT-PCR - Real time Polymerase chain reaction; Genes are represented in capital letters within parentheses.

commonly measured tumor markers are presented in Table 2.

However, in most instances tumor marker levels alone are not sufficient to diagnose cancer as it may show false elevation in non-neoplastic conditions as many tumor markers are proteins, over expressed not only by cancer cells, but also by normal tissues e.g. CA-125 is also elevated in conditions like endometriosis and nonmalignant ascites besides epithelial ovarian cancer. Some markers may be elevated in more than one type of cancer, thereby decreasing the diagnostic accuracy e.g. elevated CEA levels are found in multiple malignancies of gastrointestinal origin. Also, many markers share cross-reacting epitopes with products of normal tissues, which leads to errors in their quantitative estimation.

In conclusion, the minds of young pathologists are constantly receiving various inputs. The subdivisions and super-specialities are increasing rapidly. However, the clinical context with applied basic histo-morphology should form the foundation stone to diagnosis of cancer. The application of ancillary techniques should be carefully 
Table 2

Selected important tumor markers

\begin{tabular}{|c|c|c|c|c|}
\hline Tumor Marker & Half life & Malignancies & Non-malignant conditions & Conditions \\
\hline $\begin{array}{l}\text { AFP } \\
\text { (Alpha feto protein) }\end{array}$ & 5-7 days & $\begin{array}{l}\text { Hepatoblastoma,nonseminomatous } \\
\text { germ cell tumour (NSGCT) testis, } \\
\text { non-dysgerminomatous germ cell } \\
\text { tumour of ovary, hepatocellular } \\
\text { carcinoma (HCC), others like } \\
\text { gastric, pancreatic and lung }\end{array}$ & Cirrhosis, hepatitis & $\begin{array}{l}\text { Levels }>1000 \mathrm{ng} / \mathrm{ml} \text { in large HCC } \\
\text { while } 40 \% \text { with small respectable } \\
\text { tumors have normal levels. } \\
40 \% \text { of patients with NSGCT } \\
\text { have elevated AFP. Levels of } \\
\text { AFP along with } \alpha \text {-hCG and LDH } \\
\text { help in risk stratification of germ } \\
\text { cell tumours of testis }\end{array}$ \\
\hline $\begin{array}{l}\beta \text {-HCG (Human chronic } \\
\text { gonadotropin) }\end{array}$ & $18-48 \mathrm{hrs}$ & $\begin{array}{l}\text { Choriocarcinoma, hydatidiform } \\
\text { mole,testicular germ cell tumors, } \\
\text { others like bladder, prostate } \\
\text { and kidney }\end{array}$ & Hypogonadism & $\begin{array}{l}\text { High levels } \\
(>103 \mathrm{mIU} / \mathrm{ml}) \text { in chorio- } \\
\text { carcinoma and H-mole. Used for } \\
\text { risk stratification of gestational } \\
\text { trophoblastic neoplasms }\end{array}$ \\
\hline $\begin{array}{l}\text { CEA (Carcinoembrionic } \\
\text { antigen) }\end{array}$ & 2 weeks & $\begin{array}{l}\text { Colorectal cancers, others like breast, } \\
\text { cholangiocarcinoma, and stomach. } \\
\text { Also in liver metastases, malignant } \\
\text { ascites and pleural effusion }\end{array}$ & $\begin{array}{l}\text { Smokers, fatty liver, } \\
\text { hepatitis }\end{array}$ & $\begin{array}{l}\text { Used to follow up the colorectal } \\
\text { cancers rather than diagnoses }\end{array}$ \\
\hline
\end{tabular}

weighed and performed only when of therapeutic relevance. A complete and comprehensive knowledge or expert consultation should always be called for as and when required. Economic restraints and availability of these methodologies should not compromise on patient therapy but judicious use of these, is the need of the hour.

\section{References}

1. Diaz, Leslie K MD, Sneige, Nour MD. Estrogen Receptor Analysis for Breast Cancer: Current Issues and Keys to Increasing Testing Accuracy. Advances in Anatomic Pathology 2005; 12(1):10-19

2. Marcucci, Guido A, Mrozek, Krzysztof A, Bloomfield, Clara D. Molecular heterogeneity and prognostic biomarkers in adults with acute myeloid leukemia and normal cytogenetics. Current Opinion in Hematology 2005; 12(1):68-75.

3. Lestou VS, Ludkovski O, Connors JM, Gascoyne RD, Lam
WL, Horsman DE. Characterization of the recurrent translocation $\mathrm{t}(1 ; 1)(\mathrm{p} 36.3 ; \mathrm{q} 21.1-2)$ in non-Hodgkin lymphoma by multicolor banding and fluorescence in situ hybridization analysis. Genes Chromosomes Cancer 2003; 36(4):375-81.

4. Dabritz J, Hanfler J, Preston R, Stieler J and Oettle H. Detection of Ki-ras mutations in tissue and plasma samples of patients with pancreatic cancer using PNA-mediated PCR clamping and hybridisation probes. British Journal of Cancer 2005; 92: 405-12.

5. Xie W, Rimm DL, Lin Y, Shih WJ and Reiss M. Loss of Smad Signaling Is Associated With Poor Outcome In Human Colorectal Cancer A Tissue Microarray Analysis. Cancer J 2003; 9(4): 302-12.

6. Hazel B. Nichols, Amy Trentham-Dietz, Richard R. Love, John M. Hampton, Pham Thi Hoang Anh, D. Craig Allred, Syed K. Mohsin and Polly A. Newcomb. Differences in Breast Cancer Risk Factors by Tumor Marker Subtypes among Premenopausal Vietnamese and Chinese Women. Cancer Epidemiology Biomarkers and Prevention 2005; Vol. 14: 41-7. 